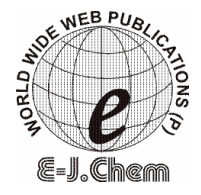

http://www.e-journals.net
ISSN: 0973-4945; CODEN ECJHAO

E-Journal of Chemistry 2009, 6(1), 289-294

\title{
Simultaneous Determination of Aceclofenac, Paracetamol and Chlorzoxazone by HPLC in Tablet Dose Form
}

\author{
UTTAM D. PAWAR, ABHIJIT V.NAIK, ARUNA V. SULEBHAVIKAR", \\ TIRUMAL A. DATAR and KIRAN.V. MANGAONKAR*
}

\author{
Department of Chemistry, \\ Mithibai College of Arts, Chauhan Institute of Science \& \\ Amrutben Jivanlal College of Commerce and Economics, \\ Vile Parle (W), Mumbai- 400 056, India. \\ "Department of Chemistry, \\ K. J. Somaiya Senior College of Science and Commerce, \\ Vidyanagar, Vidyavihar, Mumbai-400077, India \\ uttamar@indiatimes.com
}

Received 11 May 2008; Accepted 5 July 2008

\begin{abstract}
A simple, fast and precise reversed phase high performance liquid chromatographic method is developed for the simultaneous determination of aceclofenac, paracetamol and chlorzoxazone. Chromatographic separation of the three drugs was performed on an Intersil $\mathrm{C}_{18}$ column $(250 \mathrm{~mm} \times 4.6 \mathrm{~mm}, 5 \mu \mathrm{m})$ as stationary phase with a mobile phase comprising of $10 \mathrm{mM}$ potassium dihydrogen phosphate ( $\mathrm{pH}$ adjusted to 5.55 with ammonia): acetonitrile in the ratio $60: 40(\mathrm{v} / \mathrm{v})$ at a flow rate of $1.0 \mathrm{~mL} / \mathrm{min}$ and $\mathrm{UV}$ detection at $205 \mathrm{~nm}$. The linearity of aceclofenac, paracetamol and chlorzoxazone were in the range of $5.00-15.00 \mu \mathrm{g} / \mu \mathrm{L}, 25.00-75.00 \mu \mathrm{g} / \mu \mathrm{L}$ and $25.00-75.00 \mu \mathrm{g} / \mu \mathrm{L}$ respectively. The limit of detection for aceclofenac, paracetamol and chlorzoxazone was found to be $18.0 \mathrm{ng} / \mathrm{mL}, 22.0 \mathrm{ng} / \mathrm{mL}$ and $9.0 \mathrm{ng} / \mathrm{mL}$ respectively whereas, the limit of quantification was found to be $55 \mathrm{ng} / \mathrm{mL}, 65 \mathrm{ng} / \mathrm{mL}$ and $27.0 \mathrm{ng} / \mathrm{mL}$ respectively. The recovery was calculated by standard addition method. The average recovery was found to be $99.04 \%, 99.57 \%$ and $101.63 \%$ for aceclofenac, paracetamol and chlorzoxazone respectively. The proposed method was found to be accurate, precise and rapid for the simultaneous determination of aceclofenac, paracetamol and chlorzoxazone.
\end{abstract}

Keywords: HPLC, Aceclofenac, Paracetamol, Chlorzoxazone, Tablet 


\section{Introduction}

Aceclofenac (Molecular formula: $\mathrm{C}_{16} \mathrm{H}_{13} \mathrm{Cl}_{2} \mathrm{NO}_{4}$; Molecular weight: 354.19) ${ }^{1,2}$, 2-[2-[2-(2, 6dichlorophenyl) aminophenyl] acetyl] oxyacetic acid is a highly effective anti-inflammatory drug. It has been widely used for the treatment of arthritis. It works by blocking the action of a substance in the body called cyclooxygenase. Cyclooxygenase is involved in the production of various chemicals in the body, some of which are known as prostaglandin. Paracetamol (Molecular formula: $\mathrm{C}_{8} \mathrm{H}_{9} \mathrm{NO}_{2}$; Molecular weight: 151.16) ${ }^{1,2}, \mathrm{~N}$ - (4-hydroxyphenyl) acetamide is a well known analgesic drug, which is very effective treatment for the relief of pain and fever in adults and children. Paracetamol is mostly converted to inactive compounds via Phase II metabolism by conjugation with sulfate and glucuronide, with a small portion being oxidised via the cytochrome P450 enzyme system. Cytochrome P450 2E1 (CYP2E1) converts paracetamol to a highly reactive intermediary metabolite, $N$-acetyl- $p$-benzoquinone imine (NAPQI). Chlorzoxazone (Molecular formula: $\mathrm{C}_{7} \mathrm{H}_{4} \mathrm{ClNO}_{2}$; Molecular weight: 169.57) ${ }^{1,2}, 5$ chloro-2-benzoxazolone is a effective muscle relaxant. Chlorzoxazone is a centrally acting agent for painful musculoskeletal conditions. Chlorzoxazone acts primarily at the level of the spinal cord and sub cortical areas of the brain where it inhibits multisynaptic reflex action involved in producing and maintaining skeletal muscle spasm of varied etiology. The structural formuls ${ }^{1,2}$ of these three drugs are shown in Figure 1.<smiles>O=C(O)COC(=O)Cc1ccccc1Nc1c(Cl)cccc1Cl</smiles>

1. Aceclofenac<smiles>O=c1[nH]c2cc(Cl)ccc2o1</smiles>

2. Chlorzoxazone.<smiles>CC(=O)Nc1ccc(O)cc1</smiles>

3. Paracetamol.

Figure 1. The structural formulas

In this paper we have reported an HPLC method for simultaneous determination of one such combination contains $100 \mathrm{mg}$ aceclofenac, $500 \mathrm{mg}$ Paracetamol and $500 \mathrm{mg}$ chlorzoxazone. This method was developed and optimized by following ICH tripartite guidelines $^{3}$. The literature reveals single HPLC ${ }^{4}$ and two HPTLC ${ }^{5,6}$ methods reported for simultaneous determination in combination with other analgesic drug and no method was available for simultaneous determination of all these three drugs in such pharmaceutical preparations by HPLC. Therefore an RP-HPLC method was developed for determination of aceclofenac, paracetamol and chlorzoxazone from their combined dosage form. The method described is simple, fast, precise and accurate for simultaneous determination of aceclofenac, paracetamol and chlorzoxazone from pharmaceutical preparation.

\section{Experimental}

\section{Working standards and chemicals}

The formulation, Hifenac MR Tablets (containing $100 \mathrm{mg}$ of aceclofenac, $500 \mathrm{mg}$ of paracetamol and $500 \mathrm{mg}$ of chlorzoxazone) were procured from pharmacies. All working standards were obtained from TDM Labs. Sion, Mumbai with certificate of analysis. Toluene, acetonitrile, methanol and glacial acetic acid used were analytical grade. All dilutions were performed in standard volumetric flasks. 


\section{Instrument}

Chromatographic separation was preformed with Jasco high performance liquid chromatography having PU-980 HPLC isocratic pump, equipped with Jasco AS-2057 auto sampler and a Jasco UV- 970 variable wavelength detector. Chromatograms and data were recorded by means of Borwin Chromatographic software version 1.21.

\section{Working standard solution preparation}

$25 \mathrm{mg}$ of aceclofenac $(99.20 \%)$ was taken in a $25 \mathrm{~mL}$ volumetric flask. This was dissolved in minimum quantity of methanol and diluted up to the mark to get a concentration 1000 $\mu \mathrm{g} / \mathrm{mL}$ of aceclofenac. Similarly stock solutions of $1000 \mu \mathrm{g} / \mathrm{mL}$ of each paracetamol (100.31\%) and chlorzoxazone $(99.28 \%)$ were prepared in $25 \mathrm{~mL}$ volumetric flasks using methanol.

\section{Optimized chromatographic conditions}

$10 \mathrm{mM}$ Potassium dihydrogen phosphate at pH $5.55( \pm 0.05)$ with ammonia and acetonitrile in the volume of ratio $60: 40 \mathrm{v} / \mathrm{v}$.

$\begin{array}{ll}\text { Analytical column: } & \text { Intersil } \mathrm{C}_{18} \text { column }(250 \mathrm{~mm} \times 4.6 \mathrm{~mm}) 5 \mu \\ \text { UV detection: } & 205 \mathrm{~nm} \\ \text { Flow rate: } & 1.00 \mathrm{~mL} / \mathrm{min} \\ \text { Injection volume: } & 10 \mu \mathrm{L} \\ \text { Temperature: } & \text { Ambient } \\ \text { Run time: } & 25.0 \mathrm{~min} \\ \text { Retention time: } & \text { (A) Paracetamol } \sim 3.40 \mathrm{~min} \\ & \text { (B) Chlorzoxazone } \sim 11.25 \mathrm{~min} \\ & \text { (C) Aceclofenac } \sim 19.48 \mathrm{~min}\end{array}$

\section{Linearity of detector response}

Solution containing mixture of aceclofenac, paracetamol and chlorzoxazone of six different concentrations were prepared in mobile phase in $10 \mathrm{~mL}$ volumetric flasks from stock solution. The concentration range for each of the three drugs in the linearity working standard solutions were 5.00 to $15.00 \mu \mathrm{g} / \mathrm{mL}$ for aceclofenac, 25.0 to $75.0 \mu \mathrm{g} / \mathrm{mL}$ for paracetamol and 25.0 to $75.0 \mu \mathrm{g} / \mathrm{mL}$ for chlorzoxazone were prepared. $10 \mu \mathrm{L}$ of each solution was injected in three replicates. The chromatograms were recorded and the peak areas were computed. A typical HPLC chromatogram is shown in Figure 2. A linear relationship between peak areas (average peak areas of three replicates) versus concentrations was observed for aceclofenac, paracetamol and chlorzoxazone in the above linearity range. This range was selected as linear range for analytical method development of three components.

\section{Sample preparation}

Twenty tablets were weighed and average weight was calculated. These tablets were powdered. Weighed equivalent to one tablet was taken in a $100 \mathrm{~mL}$ volumetric flask; dissolved in minimum amount methanol and diluted up to the mark with methanol. That solution was then filtered through Whatman's filer paper no. 41 and the filtrate was collected in the flask. One $\mathrm{mL}$ of that filtrate was diluted to $100 \mathrm{~mL}$ with mobile phase to get $10.00 \mu \mathrm{g} / \mathrm{mL}$ of aceclofenac, $50.00 \mu \mathrm{g} / \mathrm{mL}$ of paracetamol and $50.00 \mu \mathrm{g} / \mathrm{mL}$ of chlorzoxazone. 


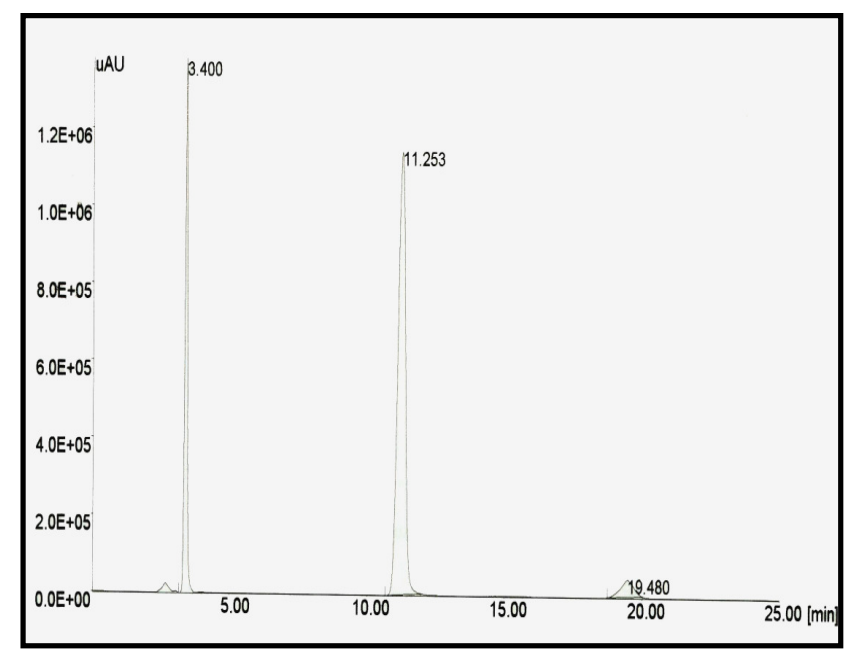

Paracetamol $\left(R_{t}=3.40\right)$, Chlorzoxazone $\left(R_{t}=11.25\right)$ and Aceclofenac $\left(R_{t}=19.48\right)$

Figure 2. Typical HPLC chromatogram.

Assay

From the above sample solution $10 \mu \mathrm{L}$ was spotted in triplicate along with same concentration of standard solution on to the plate under the optimized chromatographic conditions. The peak area values of aceclofenac, paracetamol, and chlorzoxazone were calculated. The amount of aceclofenac, paracetamol, and chlorzoxazone present in that solution were then estimated using calibration curve method. Results of assay are tabulated in Table 1.

Table 1. Results of assay experiment.

\begin{tabular}{ccccc}
\hline Drug & Labeled claim, $\mathrm{mg}$ & Amount found $(\mathrm{n}=7)$ & \% CV & \% Assay \\
\hline Aceclofenac & 100 & 99.04 & 1.88 & 99.04 \\
Paracetamol & 500 & 497.87 & 1.23 & 99.57 \\
Chlorzoxazone & 500 & 508.16 & 0.70 & 101.63 \\
\hline
\end{tabular}

\section{Recovery studies}

Recovery experiments were carried out to check for the presence of positive or negative interferences from excipients present in the formulation and to study the accuracy and precision of the method. Recovery experiment was performed by the standard addition method $^{3}$. The recovery of the added standard was studied at three different levels viz $120 \%$, $140 \%$ and $160 \%$ of the estimated amount of the drug. Each set of recovery of added standard was calculated. The results of recovery experiment are tabulated in Table 2A, $2 \mathrm{~B}$ and $2 \mathrm{C}$.

\section{The limit of quantitation ( $L O Q)$ and limit of detection (LOD)}

The limit of quantitation (LOQ) and limit of detection (LOD) was established at a signal-tonoise ratio. The LOD and LOQ of aceclofenac, paracetamol and chlorzoxazone were experimentally determined by six injections of each drug. The LOD of aceclofenac, paracetamol and chlorzoxazone were found to be $18 \mathrm{ng} / \mathrm{mL}, 22 \mathrm{ng} / \mathrm{mL}$ and $9 \mathrm{ng} / \mathrm{mL}$ respectively. The LOQ of aceclofenac, paracetamol and chlorzoxazone were found to be 55 $\mathrm{ng} / \mathrm{mL}, 65 \mathrm{ng} / \mathrm{mL}$ and $27 \mathrm{ng} / \mathrm{mL}$ respectively. 
Table 2. Results of recovery experiments (A, B, C).

Aceclofenac (A)

\begin{tabular}{|c|c|c|c|c|c|c|c|c|}
\hline \multirow[b]{2}{*}{ S. No. } & \multicolumn{4}{|c|}{ Amount of Aceclofenac in 'mg' } & \multirow[b]{2}{*}{$\begin{array}{l}\text { Mean } \\
(n=5)\end{array}$} & \multirow[b]{2}{*}{ SD } & \multirow[b]{2}{*}{$\% \mathrm{CV}$} & \multirow[b]{2}{*}{$\begin{array}{c}\% \\
\text { Recovery }\end{array}$} \\
\hline & $\begin{array}{c}\% \\
\text { Added }\end{array}$ & $\begin{array}{c}\text { Original } \\
\text { amount }\end{array}$ & $\begin{array}{c}\text { Added } \\
\text { amount }\end{array}$ & $\begin{array}{c}\text { Total } \\
\text { amount }\end{array}$ & & & & \\
\hline 1 & 0.0 & 100.00 & 0.00 & 100.00 & 101.16 & 0.92 & 0.91 & 101.16 \\
\hline 2 & 20.0 & 100.00 & 20.00 & 120.00 & 120.26 & 1.48 & 1.23 & 100.22 \\
\hline 3 & 40.0 & 100.00 & 40.00 & 140.00 & 137.16 & 1.49 & 1.09 & 97.97 \\
\hline \multirow[t]{2}{*}{4} & 60.0 & 100.00 & 60.00 & 160.00 & 159.80 & 2.59 & 1.62 & 99.88 \\
\hline & & & & & & \multicolumn{2}{|c|}{ Average Total } & 99.81 \\
\hline \multicolumn{9}{|c|}{ Paracetamol (B) } \\
\hline \multicolumn{5}{|c|}{ Amount of Paracetamol in 'mg' } & & & \multirow[b]{2}{*}{$\% \mathrm{CV}$} & \multirow[b]{2}{*}{$\%$ Recovery } \\
\hline S. No. & $\begin{array}{c}\% \\
\text { Added } \\
\end{array}$ & $\begin{array}{c}\text { Original } \\
\text { amount }\end{array}$ & $\begin{array}{c}\text { Added } \\
\text { amount }\end{array}$ & $\begin{array}{c}\text { Total } \\
\text { amount }\end{array}$ & $\begin{array}{l}\text { Mean } \\
(\mathrm{n}=5)\end{array}$ & & & \\
\hline 1 & 0.0 & 500.00 & 0.00 & 500.00 & 506.80 & 5.93 & 1.17 & 101.36 \\
\hline 2 & 20.0 & 500.00 & 100.00 & 600.00 & 602.80 & 9.93 & 1.65 & 100.47 \\
\hline 3 & 40.0 & 500.00 & 200.00 & 700.00 & 707.60 & 9.66 & 1.37 & 101.09 \\
\hline \multirow[t]{2}{*}{4} & 60.0 & 500.00 & 300.00 & 800.00 & 810.00 & 10.86 & 1.34 & 101.25 \\
\hline & & & & & & \multicolumn{2}{|c|}{ Average Total } & 101.04 \\
\hline
\end{tabular}

\begin{tabular}{|c|c|c|c|c|c|c|c|c|}
\hline \multicolumn{9}{|c|}{ Chlorzoxazone (C) } \\
\hline \multirow[b]{2}{*}{ S. No. } & \multicolumn{4}{|c|}{ Amount of Chlorzoxazone in 'mg' } & \multirow[b]{2}{*}{$\begin{array}{l}\text { Mean } \\
(n=5)\end{array}$} & \multirow[b]{2}{*}{ SD } & \multirow[b]{2}{*}{$\% \mathrm{CV}$} & \multirow[b]{2}{*}{ \%Recovery } \\
\hline & $\begin{array}{c}\% \\
\text { Added }\end{array}$ & $\begin{array}{l}\text { Original } \\
\text { amount }\end{array}$ & $\begin{array}{r}\text { Added } \\
\text { amount }\end{array}$ & $\begin{array}{l}\text { Total } \\
\text { amount }\end{array}$ & & & & \\
\hline 1 & 0.0 & 500.00 & 0.00 & 500.00 & 500.80 & 9.36 & 1.87 & 100.16 \\
\hline 2 & 20.0 & 500.00 & 100.00 & 600.00 & 593.60 & 7.47 & 1.26 & 98.93 \\
\hline 3 & 40.0 & 500.00 & 200.00 & 700.00 & 709.00 & 7.68 & 1.08 & 101.29 \\
\hline 4 & 60.0 & 500.00 & 300.00 & 800.00 & 809.00 & 10.15 & 1.25 & 101.13 \\
\hline & & & & & & Avera & e Total & 100.38 \\
\hline
\end{tabular}

(' $n$ ' each value is average of five determinations)

\section{Results and Discussion}

The Reverse Phase High Performance Liquid Chromatography method was optimized with a view to developed a stability indicating assay method. Pure drugs chromatogram was run in different mobile phases containing methanol, acetonitrile, water and different buffers in different ratios. Different columns (e.g. $\mathrm{C}_{8}, \mathrm{C}_{18}$, phenyle) with different dimentions were used. The retention time and tailing factor was calculated for each drugs and for each chromatogram. Finally $10 \mathrm{mM}$ potassium dihydrogen phosphate at $\mathrm{pH} 5.55( \pm 0.05)$ with ammonia and acetonitrile as a mobile phase in the volume of ratio 60:40 v/v and Intersil $\mathrm{C}_{18}$ analytical column was selected which gave a sharp and symmetrical peak with minimum tailing. Calibration graph was found to be linear at range 5.00 to $150.00 \mu \mathrm{g} / \mathrm{mL}, 25.00$ to $75.00 \mu \mathrm{g} / \mathrm{mL}$ and 25.00 to $75.00 \mu \mathrm{g} / \mathrm{mL}$ for the aceclofenac, paracetamol and chlorzoxazone respectively. Six different concentrations of a mixture of three drugs in the range given above were prepared and $10 \mu \mathrm{L}$ of each solution injected in HPLC. Regression analysis of the calibration data for aceclofenac, paracetamol and chlorzoxazone showed that the dependent variable (peak area) and the independent variable (concentration) were represented by the equations: 
$\mathrm{y}=\mathrm{m} \mathrm{x}+\mathrm{c}$ was found to $\mathrm{y}=146852 \mathrm{x}+(0), \mathrm{y}=139836.7 \mathrm{x}+(-620986)$ and $y=226994.3 x+7266174$ for aceclofenac, paracetamol and chlorzoxazone respectively. The correlation of coefficient $\left(\mathrm{r}^{2}\right)$ obtained was found to be $0.9984,0.9988$ and 0.9990 for aceclofenac, paracetamol and chlorzoxazone respectively. It was observed that the concentration range showed a good relationship. The limit of detection for aceclofenac, paracetamol and chlorzoxazone were found to be $18 \mathrm{ng} / \mathrm{mL}, 22 \mathrm{ng} / \mathrm{mL}$ and $9 \mathrm{ng} / \mathrm{mL}$ respectively and the limit of quantification was found to be $55 \mathrm{ng} / \mathrm{mL}, 65 \mathrm{ng} / \mathrm{mL}$ and 27 $\mathrm{ng} / \mathrm{mL}$ respectively. It proves the sensitivity of method for the drugs. The $\%$ assay or average amount of aceclofenac, paracetamol, and chlorzoxazone found to be $99.04 \%$, $99.57 \%$ and $101.63 \%$ respectively in each tablet. The average $\%$ recovery for aceclofenac, paracetamol and chlorzoxazone was found to be $99.81 \%, 101.04 \%$ and $100.38 \%$ respectively which shows that method is free from interference from excipients present in the formulation. The low values of standard deviation and coefficient of variation at each level of the recovery experiment indicate high precision of the method.

\section{Conclusion}

The high performance liquid chromatographic method for the determination of aceclofenac, paracetamol and chlorzoxazone from their fixed dosage form was found to be accurate and precise. Thus, the proposed HPLC method can be successfully applied for the routine quality control analysis of aceclofenac, paracetamol and chlorzoxazone from their fixed dosage form.

\section{Acknowledgment}

We thank Ramnarain Ruia College and TDM Labs for technical assistance in conducting this study. We gratefully acknowledge the excellent cooperation of Dr. R. T. Sane, Dr. Vikas Vaidya and Ms Nutan Prabhu-Navelkar.

\section{References}

1. Susan Budavari, Maryadele J O’ Neil, Ann Smith, Patricia E, Heckelman, Joanne F and Kinneary, The Merck Index, Merck Research Laboratories, $13^{\text {rd }}$ Ed., 2001.

2. George Lunn, HPLC methods for pharmaceutical analysis, 1999, 2, 5, 367.

3. ICH Q2A, Text on validation of analytical procedures, International Conference on Harmonization tripartite guidelines, adapted 27 Oct 1994B.

4. Gopinath R, Rajan S, Meyyanthan S N, Krishnaveni N and Suresh B A, J Pharma Sci., 2007, 69, 137.

5. Fried J and Sherma, Thin Layer Chromatography, $4^{\text {th }}$ Ed., 1994. 81, New York, 1994.

6. Ramesh T, Sane and Manjusha Gadgil, J Planar Chromatogr-Mod TLC, 2002, 15, 76. 


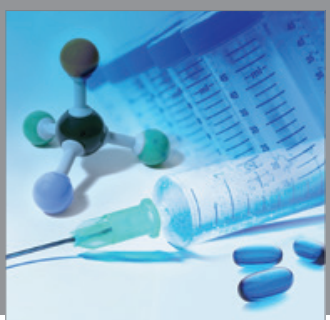

International Journal of

Medicinal Chemistry

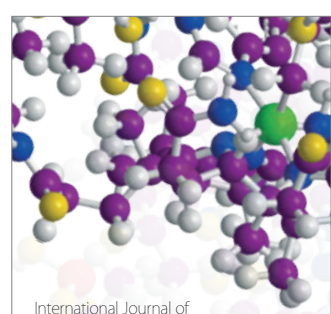

Carbohydrate Chemistry

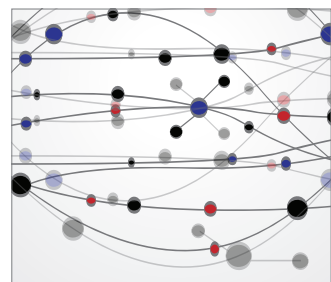

The Scientific World Journal
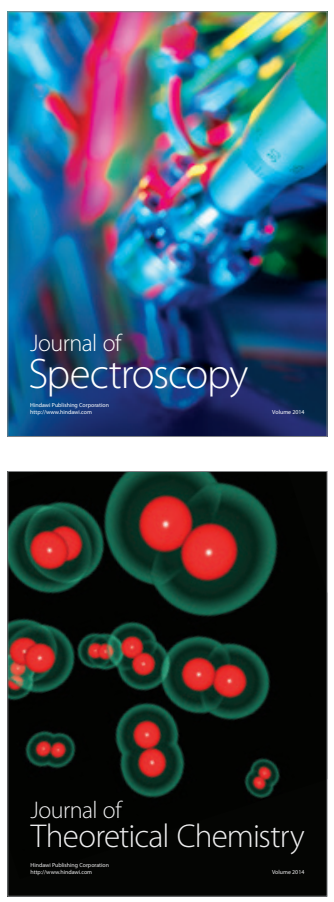
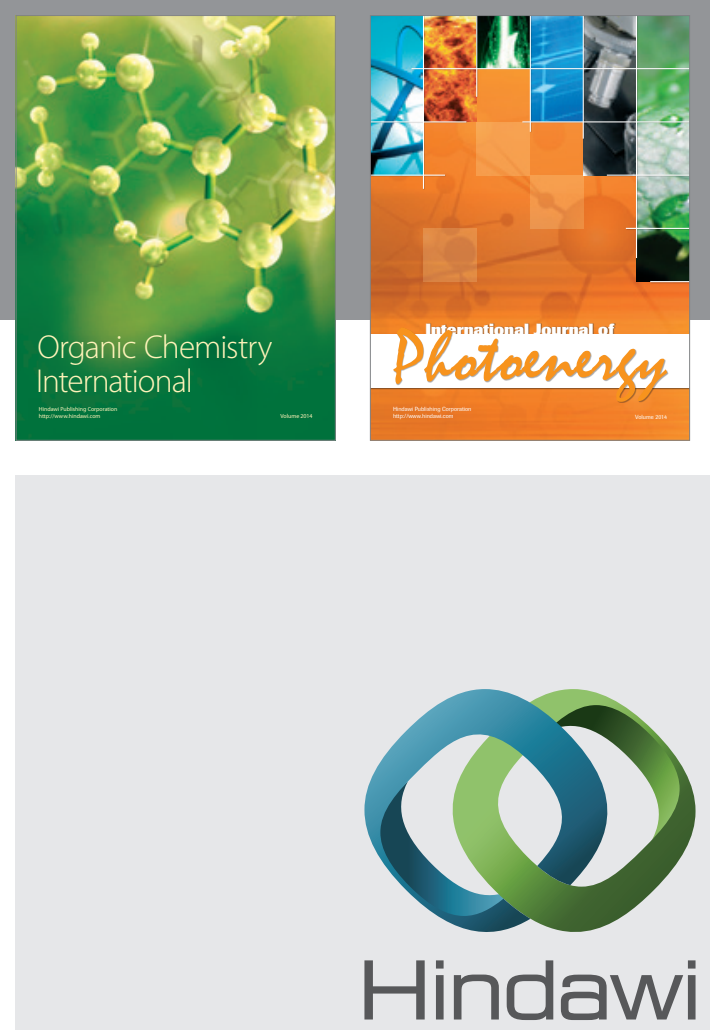

Submit your manuscripts at

http://www.hindawi.com
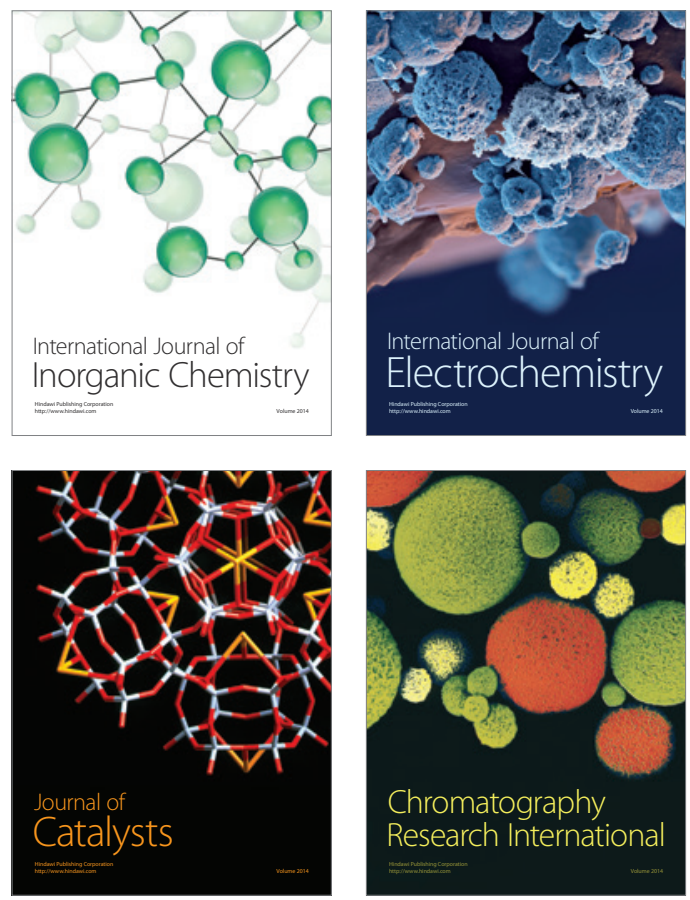
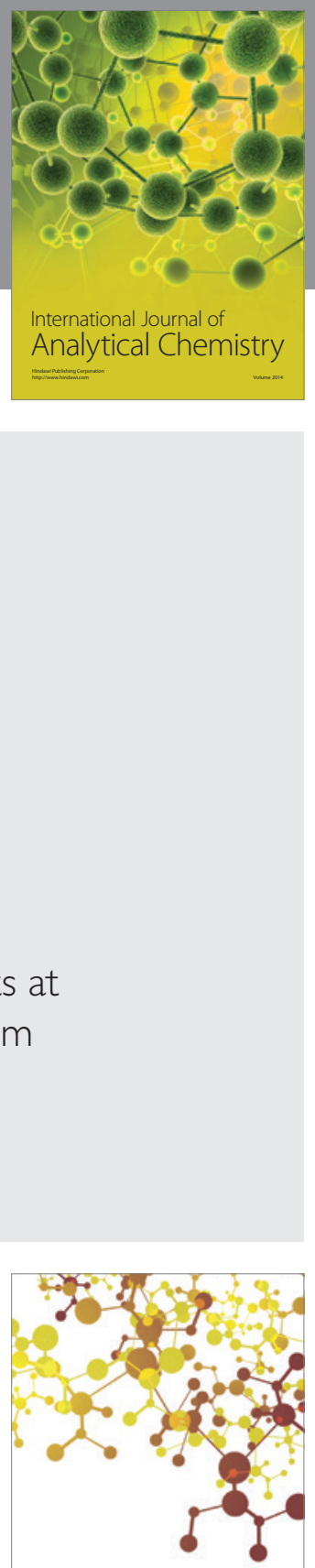

Journal of

Applied Chemistry
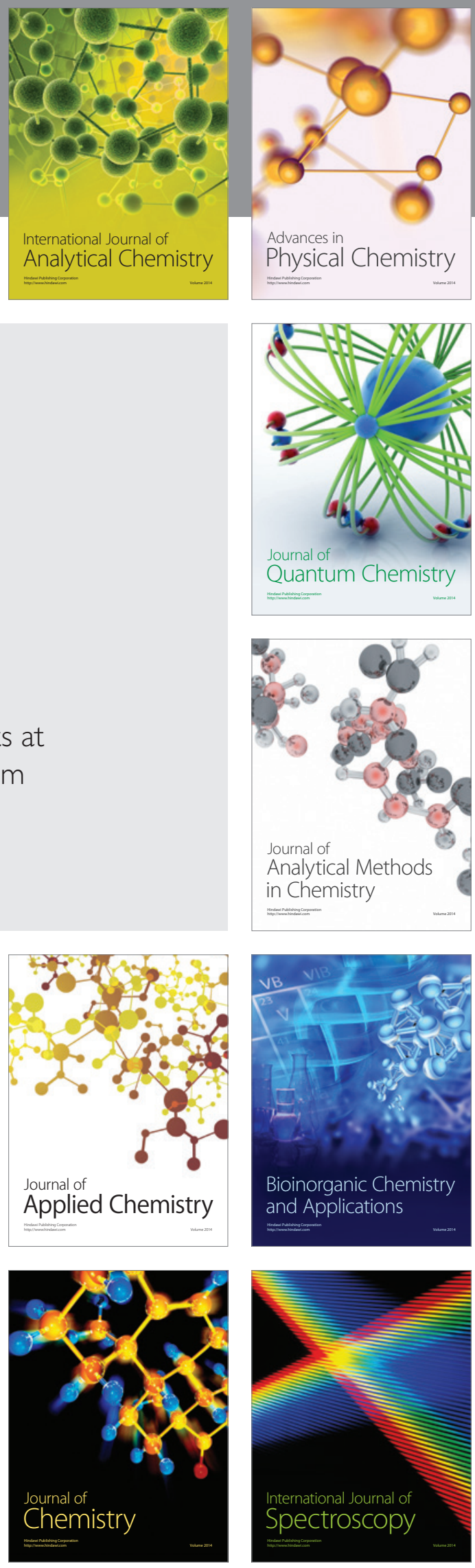